\title{
Evaluation of manual resuscitators used in ICUs in Brazil*
}

\author{
Avaliação de reanimadores manuais utilizados em UTls brasileiras
}

\author{
Tatiana de Arruda Ortiz, Germano Forti Junior, Márcia Souza Volpe, Marcelo do \\ Amaral Beraldo, Marcelo Britto Passos Amato, Carlos Roberto Ribeiro Carvalho, \\ Mauro Roberto Tucci
}

\begin{abstract}
Objective: To evaluate the performance of manual resuscitators (MRs) used in Brazil in accordance with international standards. Methods: Using a respiratory system simulator, four volunteer physiotherapists employed eight MRs (five produced in Brazil and three produced abroad), which were tested for inspiratory and expiratory resistance of the patient valve; functioning of the pressure-limiting valve; and tidal volume $\left(\mathrm{V}_{\mathrm{T}}\right)$ generated when the one-handed and two-handed techniques were used. The tests were performed and analyzed in accordance with the American Society for Testing and Materials (ASTM) F920-93 criteria. Results: Expiratory resistance was greater than $6 \mathrm{cmH}_{2} \mathrm{O} \cdot \mathrm{L}^{-1} \cdot \mathrm{s}^{-1}$ in only one MR. The pressure-limiting valve, a feature of five of the MRs, opened at low pressures $\left(<17 \mathrm{cmH}_{2} 0\right)$, and the maximal pressure was 32.0-55.9 $\mathrm{cmH}_{2} 0$. Mean $\mathrm{V}_{\mathrm{T}}$ varied greatly among the MRs tested. The mean $\mathrm{V}_{\mathrm{T}}$ values generated with the one-handed technique were lower than the 600 $\mathrm{mL}$ recommended by the ASTM. In the situations studied, mean $\mathrm{V}_{\mathrm{T}}$ was generally lower from the Brazilian-made MRs that had a pressure-limiting valve. Conclusions: The resistances imposed by the patient valve met the ASTM criteria in all but one of the MRs tested. The pressure-limiting valves of the Brazilian-made MRs usually opened at low pressures, providing lower $\mathrm{V}_{\mathrm{T}}$ values in the situations studied, especially when the one-handed technique was used, suggesting that both hands should be used and that the pressure-limiting valve should be closed whenever possible.
\end{abstract}

Keywords: Materials testing; Positive-pressure respiration; Equipment safety; Equipment design; Respiration, artificial; Resuscitation.

\section{Resumo}

Objetivo: Avaliar o desempenho de reanimadores manuais (RMs) utilizados no Brasil conforme critérios definidos por uma norma internacional. Métodos: Utilizando um simulador do sistema respiratório, oito RMs manuais (cinco produzidos no Brasil e três importados) foram avaliados em relação a resistência inspiratória e expiratória da válvula para o paciente; funcionamento da válvula limitadora de pressão; e volume corrente $\left(\mathrm{V}_{\mathrm{T}}\right)$ gerado por quatro fisioterapeutas voluntários, utilizando uma ou duas mãos. Para a realização e análise dos testes, foram utilizados critérios sugeridos pela norma da American Society for Testing and Materials (ASTM) F920-93. Resultados: A resistência expiratória foi superior a $6 \mathrm{cmH}_{2} \mathrm{O} \cdot \mathrm{L}^{-1} \cdot \mathrm{s}^{-1} \mathrm{em}$ apenas um dos RMs testados. A válvula limitadora de pressão, presente em cinco RMs, abriu em baixas pressões $\left(<17 \mathrm{cmH}_{2} 0\right)$, e a pressão máxima variou de 32,0-55,9 $\mathrm{cmH}_{2} \mathrm{O}$. Houve grande variação da média de $\mathrm{V}_{\mathrm{T}}$ obtido pelos diferentes RMs. Os valores médios de $V_{T}$ utilizando uma mão foram inferiores ao sugerido pela ASTM $(600 \mathrm{~mL}) .0 \mathrm{~V}_{\mathrm{T}}$ médio, nas situações estudadas, foi geralmente menor nos RMs nacionais com válvula limitadora de pressão. Conclusões: As resistências impostas pela válvula do paciente estão de acordo com os critérios da ASTM, com exceção de um RM. As válvulas limitadoras de pressão dos RMs nacionais geralmente abrem em baixas pressões, determinando o fornecimento de um menor $\mathrm{V}_{\mathrm{T}}$ nas situações estudadas, principalmente com o uso de uma mão, o que sugere que a ventilação deva ser feita com as duas mãos e a válvula limitadora de pressão deva ser fechada sempre que possível.

Descritores: Teste de materiais; Respiração com pressão positiva; Segurança de equipamentos; Desenho de equipamento; Respiração artificial; Ressuscitação.

\footnotetext{
* Study carried out in Laboratório de Investigação Médica 09 (LIM09, Laboratory for Medical Research 09), specializing in Pulmonology, University of São Paulo School of Medicine, São Paulo, Brazil.

Correspondence to: Mauro R. Tucci. Laboratório de Pneumologia LIM09, Faculdade de Medicina da Universidade de São Paulo, Avenida Dr. Arnaldo, 455, Sala 2144, $2^{\circ}$ andar, CEP 01246-903, São Paulo, SP, Brasil.

Tel. 5511 3061-7361. Fax: 5511 3061-2492. E-mail: mrotucci@gmail.com

Financial support: This study received financial support from the Fundação de Amparo à Pesquisa do Estado de São Paulo (FAPESP, São Paulo Research Foundation), the Laboratory for Medical Research of the University of São Paulo School of Medicine Hospitals das Clínicas, and the Financiadora de Estudos e Projetos (FINEP, Brazilian Financing Agency for Studies and Projects). Submitted: 21 February 2013. Accepted, after review: 6 September 203.
} 


\section{Introduction}

Manual resuscitators (MRs) are used for manual ventilation of patients. They are also known as "ambu", which is the trademark of a resuscitator and the term used as a synonym for MR by professionals in Brazil and other countries. ${ }^{(1,2)}$ Being used in ICUs in order optimize oxygenation and facilitate the removal of secretion in patients on invasive mechanical ventilation, MRs are also used for intra-hospital transport and as a source of temporary ventilation in intubated and nonintubated patients. ${ }^{(1-4)} 0 \mathrm{n}$ the basis of their inflation mechanism, MRs can be classified as self-inflating or flow-inflating, ${ }^{(1,5)}$ the former being the most commonly used type in 1CUs in Brazil.

Self-inflating MRs, which is the type of MR evaluated in the present study, consist of a compressible self-inflating bag, an inflating valve, and an inspiratory/expiratory valve (patient valve; Figure 1). ${ }^{(5,6)}$ When the bag is compressed by the operator, the patient valve occludes the expiratory port and allows the air within the bag to flow to the patient; when the pressure within the bag ceases, the patient valve returns to its normal position, occluding the communication of the bag with the patient and allowing the air coming from the patient to be exhaled through the expiratory port. A drop in pressure within the bag during exhalation causes the inflating valve to open, allowing the air to enter the bag. ${ }^{(5,6)}$ Additional components of this type of MR include ${ }^{(5,6)}$ a device for enriching the oxygen mixture, a positive end-expiratory pressure (PEEP) valve, and a pressure-limiting valve (PLV), the use of which in adult patients is not in accordance with the American Society for Testing and Materials (ASTM) criteria. ${ }^{(7)}$

In the literature, there are studies evaluating the performance and safety of MRs available in other countries in accordance with international technical standards. ${ }^{(8-10)}$ Comparative studies allow the identification of problems and the improvement of these devices. The objective of the present study was to evaluate the characteristics and performance of some of the self-inflating MRs for use in adult patients that are available in the Brazilian market, in accordance with international standards.

\section{Methods}

The present study was approved by the Research Ethics Committee of the University of São Paulo School of Medicine Hospital das Clínicas and was carried out in the Experimental Mechanical Ventilation Laboratory of the Department of Pulmonology of the same institution in 2006.

We evaluated eight MRs, of which five were manufactured in Brazil (J.G. Moriya, São Paulo; Oxigel, São Paulo; Protec Equipamentos Médico-
(A)

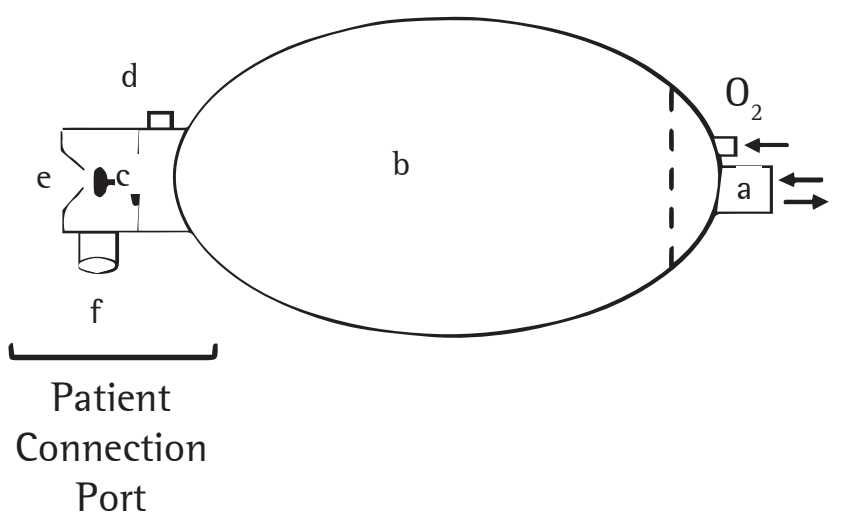

(B)

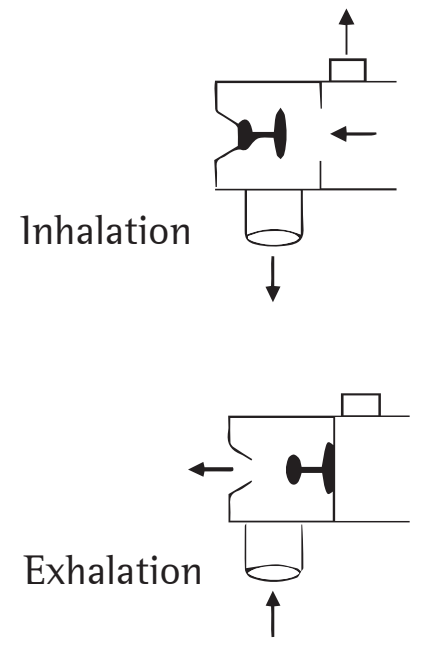

Figure 1 - Schematic representation of the manual resuscitator. Figure A illustrates all of the components of the resuscitator, and figure B illustrates only the patient connection port, highlighting the positioning of the patient valve during inhalation and exhalation.

a: connection port of the oxygen reservoir with an inflation valve; b: inflating bag; c: patient valve; d: pressure-limiting valve (acts only during inhalation); e: expiratory port; and f: patient connection port. 
Table 1 - Characteristics of the manual resuscitators for adults as described by the manufacturers.

\begin{tabular}{|c|c|c|c|c|c|c|}
\hline $\begin{array}{l}\text { Manual } \\
\text { resuscitator }\end{array}$ & $\begin{array}{l}\text { Type de } \\
\text { valve }\end{array}$ & $\begin{array}{c}\text { Type of } \\
\text { bag }\end{array}$ & $\begin{array}{l}\text { Capacity of } \\
\text { the bag, mL }\end{array}$ & $\begin{array}{l}\text { Pressure-limiting } \\
\text { valve, } \mathrm{cmH}_{2} \mathrm{O}\end{array}$ & $\begin{array}{l}\text { Unidirectional } \\
\text { inspiratory valve }\end{array}$ & $\begin{array}{c}\text { Patient } \\
\text { connection } \\
\text { port }\end{array}$ \\
\hline $\begin{array}{l}\text { 1. Ambu Silicone } \\
\text { Resuscitator }\end{array}$ & diaphragm & silicone & 1,500 & - & yes & $360^{\circ}$ swivel \\
\hline 2. Ambu SPUR & diaphragm & silicone & 1,500 & - & yes & $360^{\circ}$ swivel \\
\hline $\begin{array}{l}\text { 3. Hudson } \mathrm{RCl} \\
\text { Lifesaver }\end{array}$ & duckbill & silicone & 1,600 & - & yes & $360^{\circ}$ swivel \\
\hline 4. J.G. Moriya & diaphragm & silicone & 1,700 & $40 \pm 5$ up to 75 & yes & fixed \\
\hline 5. Oxigel & $\begin{array}{l}\text { spring and } \\
\text { disk }\end{array}$ & vinyl & 1,200 & 40 & yes & fixed \\
\hline $\begin{array}{l}\text { 6. Protec Basic } \\
\text { Silicone }\end{array}$ & diaphragm & silicone & 1,600 & $35-45$ & yes & fixed \\
\hline 7. RWR & duckbill & silicone & 2,500 & $35-45$ & yes & fixed \\
\hline 8. Unitec & diaphragm & vinyl & 1,000 & ND & yes & fixed \\
\hline
\end{tabular}

ND: no data. Note: from 2006 to this writing, devices 1, 2, 3, 4, and 7 did not change significantly. In device 5, the current patient connection port is a swivel. In device 6 , the color of the silicone was changed from blue to transparent. In device 8 , the capacity of the bag was increased from 1,000 to $1,500 \mathrm{~mL}$.

Hospitalares, São Paulo; RWR Equipamentos Hospitalares, São Bernardo do Campo; and Unitec Ind. e Com. de Aparelhos Hospitalares Ltda., São Paulo), two were manufactured in Denmark (Ambu ${ }^{\circledR}$ Silicone Resuscitator and $\mathrm{Ambu}^{\circledR}$ SPUR; Ambu A/S, Ballerup, Denmark), and one was manufactured in the USA (Hudson $\mathrm{RCl}^{\oplus}$ Lifesaver; Hudson RCl, Durham, NC, USA). The MRs tested were lent by the manufacturers or their representatives in Brazil. All of the models are still being marketed, and the updates of the MRs since the present study was carried out to this writing are described in Table 1.

Since there are no Brazilian standards defining the characteristics for the manufacture and marketing of MRs, the present evaluation used the ASTM criteria, Designation F920$93,^{(7)}$ which are equivalent to the International Organization for Standardization 8382 criteria, ${ }^{(11)}$ used in other countries. Using a respiratory system simulator, the following criteria were evaluated: resistance imposed by the patient valve during the inspiratory and expiratory phases; functioning of the PLV; and tidal volume $\left(V_{T}\right)$ delivered by the MR. In accordance with the ASTM criteria, the following specifications should be met: a drop $<5 \mathrm{cmH}_{2} \mathrm{O}$ in inspiratory and expiratory pressure in the presence of a flow of $50 \mathrm{~L} / \mathrm{min}$, leading to resistance < $6 \mathrm{cmH}_{2} \mathrm{O} \cdot \mathrm{L}^{-1} \cdot \mathrm{s}^{-1}$; the use of a PLV is not mandatory for MRs for adults, but, if this valve is available, it should be possible to close it; a $V_{T} \geq 600 \mathrm{~mL}$ should be delivered to adult patients (weight $\geq 40 \mathrm{~kg}$ ), with resistance of 20 $\mathrm{cmH}_{2} \mathrm{O} \cdot \mathrm{L}^{-1} \cdot \mathrm{s}^{-1}$ and compliance of $0.02 \mathrm{~L} / \mathrm{cmH}_{2} \mathrm{O}$, using the one-handed technique (maximum hand size, $185 \mathrm{~mm}$ ).

The measurement system consisted of a plastic tube to which pressure and flow sensors were connected (Figure 2). The signals from the sensors were amplified and stored on a computer for subsequent analysis with the Labview ${ }^{\oplus}$ software (National Instruments, TX, USA). The signal sampling frequency was $200 \mathrm{~Hz}$.

In order to measure inspiratory and expiratory resistance, a mechanical ventilator (Bear $5^{\infty}$; Bear Medical Systems, Riverside, (A, USA) was connected to one end of the plastic tube with the sensors (Figure 2). The ventilator was set to the controlled volume mode, with a constant inspiratory flow of $60 \mathrm{~L} / \mathrm{min}$ and a PEEP of zero $\mathrm{cmH}_{2} \mathrm{O}$. In the evaluation of expiratory resistance, the patient connection port of the MR was attached to the other end of the plastic tube, and the air from the ventilator left through the expiratory port into room air (Figure 2). In the evaluation of inspiratory resistance, the MR was disassembled and only the proximal portion of the set, without the bag, was used (Figure 2). The part of the MR that is connected to the bag was attached to the other end of the plastic tube, and the air left through the patient connection port to the environment. The PLV, when present, was occluded. The Ambu ${ }^{\otimes}$ Silicone Resuscitator was not tested because it could not be disassembled. 
The two resistances were calculated as the difference between the proximal and distal pressure to the valve (distal pressure was not measured, because it was equal to zero, since the system was open to the environment), divided by the measured flow.

For the testing of $\mathrm{V}_{\mathrm{T}}$, the MRs were connected to the plastic tube with the sensors, and this tube was connected to a tracheal cannula of $8.5 \mathrm{~mm}$ in diameter (Rusch, Montevideo, Uruguay), the distal portion of which, with the cuff inflated, was fitted into another plastic tube that was connected to a respiratory system simulator (TTL $2600^{\circ}$; Michigan Instruments ${ }^{\circ}$, Grands Rapids, MI, USA; Figure 2). The simulator allowed the compliance of the bellows to be set with springs; resistance was set with nonlinear resistors.

Four volunteer ICU physiotherapists in the city of São Paulo (two males and two females) operated the MRs. The size of the dominant hand (from the wrist to the tip of the middle finger) was $200 \mathrm{~mm}$ for male $1,188 \mathrm{~mm}$ for male 2, $175 \mathrm{~mm}$ for female 1 , and $160 \mathrm{~mm}$ for female 2 . The physiotherapists were instructed to inflate the model as if they were ventilating a patient, first using the one-handed technique and then using the two-handed technique, with the eight MRs, which were tested in a random sequence, under two conditions of resistance and compliance: 1) "ASTM" condition-compliance of $0.02 \mathrm{~L} / \mathrm{cmH}_{2} \mathrm{O}$ and resistance of $20 \mathrm{cmH}_{2} \mathrm{O}$. $\mathrm{L}^{-1} \cdot \mathrm{S}^{-1}$, in accordance with the ASTM criteria; ${ }^{(7)}$ and 2) "normal" condition-compliance of 0.05 $\mathrm{L} / \mathrm{cmH}_{2} \mathrm{O}$ and resistance of $5 \mathrm{cmH}_{2} \mathrm{O} \cdot \mathrm{L}^{-1} \cdot \mathrm{s}^{-1}$, simulating a patient without lung disease.

ln order to calculate $V_{T}$, three respiratory cycles were analyzed, all of which were randomly selected among the recorded cycles (a minimum of 10 per test condition). Since each volunteer (totaling four) handled eight MRs, using the one-handed and two-handed techniques, in two distinct clinical settings (ASTM condition and normal condition), 128 tests were performed.

Of the eight MRs, five were equipped with a PLV and were submitted to this test. The ventilator, connected to one end of the measurement system (with a flow sensor and a pressure sensor), was set to the controlled volume mode, with an

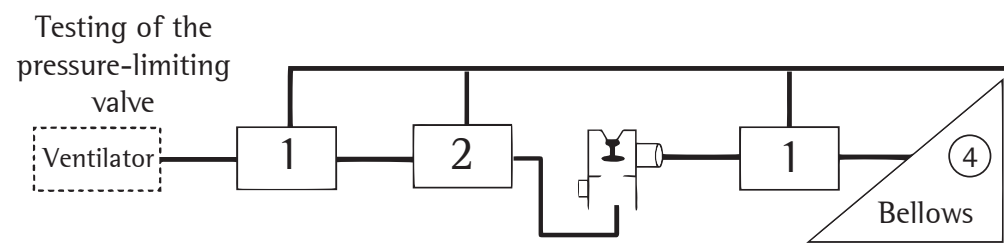

Testing of resistance

of the inspiratory valve

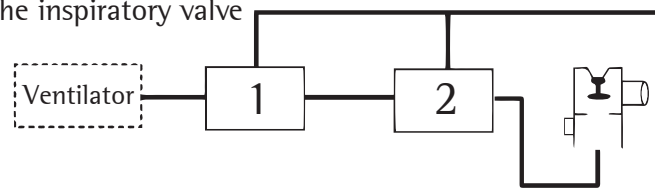

Testing of resistance

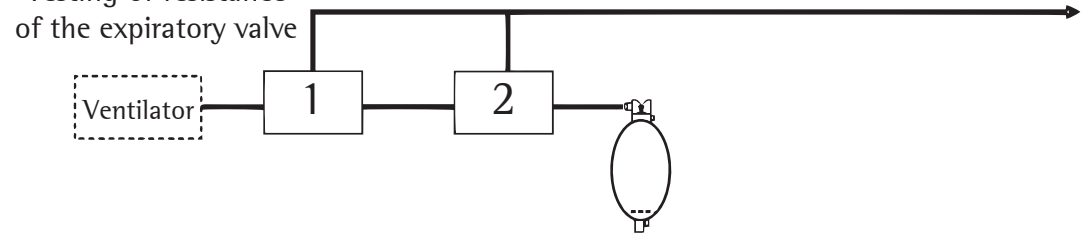

Computer

Testing of tidal

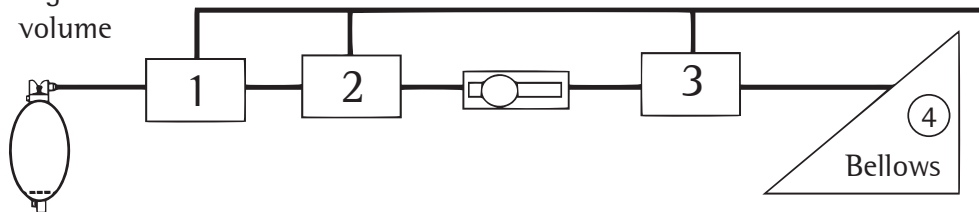

Figure 2 - Schematic representation of the experimental system.

1: proximal or distal flow sensor; 2: pressure sensor; 3: resistor; and 4: alveolar pressure sensor. 
inspiratory flow of $20 \mathrm{~L} / \mathrm{min}$, a $\mathrm{V}_{\mathrm{T}}$ of $1,800 \mathrm{~mL}$, and a PEEP of zero $\mathrm{cmH}_{2} \mathrm{O}$. A part of the MR was connected to the other end, as were another (distal) flow sensor and the simulator, in sequence (Figure 2). The pressure alarm of the mechanical ventilator was deactivated. We determined the pressure at which the PLV opened and allowed air leaks (a time point that could be identified when the flow in the distal sensor decreased in relation to that in the proximal sensor), this pressure being referred to as "opening pressure", and determined the pressure at which all air sent by the ventilator passed only through the PLV (a time point at which the distal flow was equal to zero), this pressure being referred to as "maximal pressure". The functioning of the valve was considered appropriate if the opening pressure was within the pressure interval suggested by the manufacturers, in general, values greater than 35-40 $\mathrm{cmH}_{2} \mathrm{O}$ (Table 1).

For each MR, only one inspiratory and expiratory resistance value was shown, because the variation between the cycles was negligible. The testing of the PLV was performed only once per MR. The $\mathrm{V}_{\mathrm{T}}$ values were expressed as mean and standard deviation and were evaluated by multivariate analysis using a mixed linear regression model for each of the four conditions studied: $\mathrm{V}_{\mathrm{T}}$ generated with the one-handed technique under the ASTM and normal conditions; and $\mathrm{V}_{\mathrm{T}}$ generated with the two-handed technique under the same two conditions. The physiotherapists and the MRs were evaluated as fixed effects. Post hoc tests with Sidak correction were used for comparisons of the $V_{T}$ values among the physiotherapists and among the MRs. For this analysis, we used the Statistical Package for the Social Sciences, version 17 for Windows (SPSS Inc., Chicago, IL, USA). Values of $p<0.05$ were considered significant.

\section{Results}

Table 1 shows the characteristics of the MRs tested. The most common type of patient valve was a diaphragm, and the most common bag material was silicone. The capacity of the bag of each MR varied (1,000-2,500 mL). The three imported MRs did not have a PLV, which was a feature of the five Brazilian-made MRs, and, in the MR manufactured by RWR, the PLV could be closed without there being any leaks. Another difference observed between the imported and the Brazilian-made MRs was that the patient connection port was fixed in the five Brazilian-made MRs, whereas, in the imported ones, this connection port was a " $360^{\circ}$ swivel".

Table 2 describes the results of the tests evaluating the resistances of the patient valve during inhalation and exhalation, as well as the functioning of the PLV. Only in the Protec RM did expiratory resistance exceeded the limit set by the ASTM criteria $\left(<6 \mathrm{cmH}_{2} 0 \cdot \mathrm{L}^{-1} \cdot \mathrm{s}^{-1}\right)$. In the other MRs tested, the resistances met those criteria, the highest inspiratory resistance being found in the Oxigel MR $\left(5.69 \mathrm{cmH}_{2} \mathrm{O}\right.$. $\left.\mathrm{L}^{-1} \cdot \mathrm{S}^{-1}\right)$. The PLV, a feature of five of the MRs, opened at low pressures $\left(<17 \mathrm{cmH}_{2} 0\right)$, and the maximal pressure was 32.0-55.9 $\mathrm{cmH}_{2} 0$.

The mean delivered $V_{T}$ values, by MR (Table 3) and by physiotherapist (Table E1, available online at http://www.jornaldepneumologia. com.br/detalhe_artigo.asp?id=2212), varied. In the situations evaluated (handling of the eight MRs, with the use of the one-handed and two-handed techniques, in two distinct clinical settings-ASTM condition and normal condition), there were significant differences ( $p<0.001)$ among the MRs and among the physiotherapists. All of the MRs, whenever the one-handed technique was used under the ASTM condition, delivered a lower $\mathrm{V}_{\mathrm{T}}$ than that recommended by the ASTM $(\geq 600 \mathrm{~mL})$. Only the two models of MR manufactured by Ambu A/S delivered a $V_{T} \geq 600 \mathrm{~mL}$ when the one-handed technique was used, but only during the simulation of the normal clinical condition. Even when the two-handed technique was used, the MRs manufactured by Oxigel and RWR did not deliver the minimal $\mathrm{V}_{\mathrm{T}}$ under the ASTM clinical condition, whereas the MRs manufactured by Protec and Unitec, regardless of the clinical setting simulated, delivered a $\mathrm{V}_{\mathrm{T}}<600 \mathrm{~mL}$.

In addition, when we observe the results reported in Table 3, we can see that the $V_{T}$ values generated under the normal clinical condition were, in general, higher than were those generated under the ASTM condition, which simulates a pulmonary condition with lower compliance and higher resistance, and that most of the $\mathrm{V}_{\mathrm{T}}$ values obtained with the MRs that did not have a PLV were higher than were those obtained with the MRs that had a PLV. 


\section{Discussion}

The main findings of the present study can be summarized as follows: 1) the (inspiratory and expiratory) resistances of the patient valve met the ASTM criteria in all but one of the MRs tested; 2) the eight RMs evaluated did not deliver the minimal $\mathrm{V}_{\mathrm{T}}$ under conditions standardized by those same criteria $\left(\mathrm{V}_{\mathrm{T}} \geq 600 \mathrm{~mL}\right.$, with the use of the one-handed technique, under the ASTM clinical condition); 3) the use of the two-handed technique did not solve the problem in four MRs $\left(\mathrm{V}_{\mathrm{T}}\right.$ remained $\left.<600 \mathrm{~mL}\right)$; and 4$)$ the PLV present in the Brazilian-made MRs usually led to the delivery of a lower $\mathrm{V}_{\mathrm{T}}$ than that delivered by the MRs that did not have a PLV.

In Brazil, there have been few published studies evaluating MRs for adult patients, commonly used in ICUs in the country. ${ }^{(5,12,13)}$ Although those studies investigated important characteristics, such as the oxygen fraction delivered by MRs with and without an oxygen reservoir, the present study evaluated other equally important properties that had not yet been reported in the national literature.

Regarding the evaluation of resistance of the patient valve during inhalation and exhalation, all of the MRs tested were within the specifications of the ASTM, except for the Protec MR, in which expiratory resistance was $7.91 \mathrm{cmH}_{2} \mathrm{O}$. $\mathrm{L}^{-1} \cdot \mathrm{s}^{-1}$. This result is not surprising, given that international studies had described MRs in which the resistances of the patient valve were higher than recommended. ${ }^{(14,15)}$ It is of note that higher expiratory pressure translates to longer exhalation, which can cause air trapping (auto-PEEP) and risk of barotrauma, ${ }^{(15)}$ especially when the MR is handled at a high respiratory rate and a high $\mathrm{V}_{\mathrm{T}}$.

For the evaluation of the $V_{T}$ generated with the one-handed and two-handed techniques, we selected male and female volunteers, because it is known that the $V_{T}$ obtained varies with the gender of the operator $\left(V_{T}\right.$ is lower for female operators). ${ }^{(16)}$ Mean $\mathrm{V}_{\mathrm{T}}$ varied greatly among the MRs tested, a finding that had been reported in other studies. ${ }^{(17)}$ We observed that some Brazilianmade MRs delivered a low $\mathrm{V}_{\mathrm{T}}$ even with the use of the two-handed technique, which generates a higher $\mathrm{V}_{\mathrm{T}}$ than does the one-handed technique. $(2,17,18)$ Other authors had reported, even in normal compliance simulations, $\mathrm{V}_{\mathrm{T}}$ values lower than 600 $\mathrm{mL} .{ }^{(17)}$ However, in the study by Mazzolini et al., ${ }^{(10)}$ which evaluated 16 disposable MRs manufactured abroad, only three MRs did not deliver the minimal $V_{T}$ recommended by the ASTM ( $\left.\geq 600 \mathrm{~mL}\right)$.

It is possible that various factors influenced the results for $V_{T}$. One factor that seems to have led to increased $V_{T}$ values was the size of the hands of one of the physiotherapists $(200 \mathrm{~mm}$, a larger size than that recommended by the criteria, Male 1, Table E1, available online at http://www.jornaldepneumologia. com.br/detalhe_artigo.asp?id=2212). This association between delivered $V_{T}$ and hand size has been described by other authors. ${ }^{(6,8,17,18)}$ Factors that could lead to low volumes are the size ${ }^{(18)}$ and the material of the bag of the resuscitator tested. ${ }^{(8)}$ The volume of air in the bag is not totally delivered to the patient when the bag is compressed, and, in general, the volume of the bag should be twice the volume to be delivered. ${ }^{(8)} \mathrm{A}$ bag made of a material that is not very compliant (such as polyvinyl) can lead to a lower $\mathrm{V}_{\mathrm{T}}{ }^{(8)}$ In our study, the MR that delivered the lowest $\mathrm{V}_{\mathrm{T}}$ (Unitec) had the bag with the lowest volume, and, in addition, this bag was made of polyvinyl. It is of note that $\mathrm{V}_{\mathrm{T}}$ was generally lower from the Brazilian-made MRs than from the imported ones, except for the MR manufactured by RWR, which generated a higher $\mathrm{V}_{\mathrm{T}}$, probably because the capacity of the bag was $2,500 \mathrm{~mL}$.

Table 2 - Inspiratory and expiratory resistance of the patient valve and evaluation of the pressure-limiting valve.

\begin{tabular}{lccc}
\hline Manual resuscitator & $\begin{array}{c}\text { Inspiratory resistance, } \\
\mathrm{cmH}_{2} \mathrm{O} \cdot \mathrm{L}^{-1} \cdot \mathrm{s}^{-1}\end{array}$ & $\begin{array}{c}\text { Expiratory resistance, } \\
\mathrm{cmH}_{2} \mathrm{O} . \mathrm{L}^{-1} \cdot \mathrm{s}^{-1}\end{array}$ & $\begin{array}{c}\text { Limiting valve: opening } \\
\text { pressure/maximal pressure, } \\
\mathrm{cmH}_{2} \mathrm{O}\end{array}$ \\
\hline 1. Ambu & 2.96 & 3.29 & $\mathrm{~N} / \mathrm{A}$ \\
2. Ambu Spur & - & 3.17 & $\mathrm{~N} / \mathrm{A}$ \\
3. Hudson/RCl & 3.16 & 4.42 & $\mathrm{~N} / \mathrm{A}$ \\
4. Moriya & 2.11 & 3.08 & $16.6 / 55.9$ \\
5. Oxigel & 5.69 & 3.69 & $13.4 / 37.6$ \\
6. Protec & 2.77 & 7.91 & $7.2 / 33$ \\
7. RWR & 2.66 & 3.62 & $6.1 / 32$ \\
8. Unitec & 1.54 & 1.75 & $14.6 / 47.3$ \\
\hline
\end{tabular}




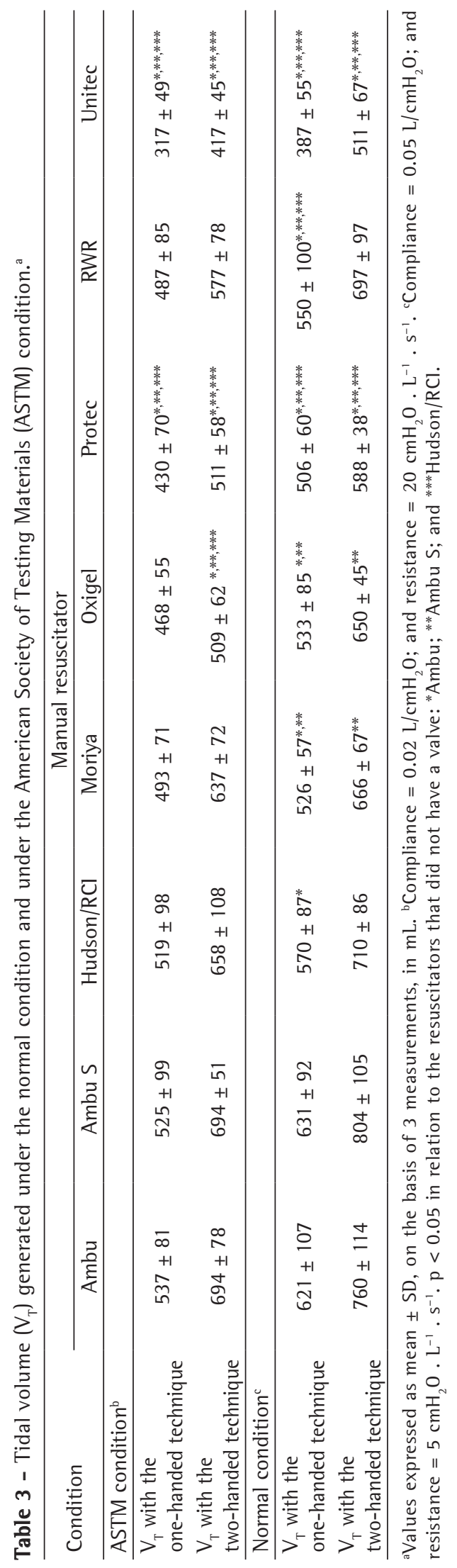


One could question whether the low $V_{T}$ values found for some of the MRs tested resulted from fatigue of the volunteers. However, the study by Hess et al., ${ }^{(16)}$ which evaluated the effect of fatigue caused by ventilation with a MR for 30 min under low compliance $\left(20 \mathrm{~mL} / \mathrm{cmH}_{2} \mathrm{O}\right)$, found no reduction in $\mathrm{V}_{\mathrm{T}}$ after 30 minutes for the 14 volunteers evaluated. Considering that, in our study, total test time for each of the MRs was approximately one minute, which would total eight minutes for each of the four situations evaluated (two impedance values with the use of the one-handed and two-handed techniques), and that there was a rest break between each measurement, it seems unlikely that the occurrence of fatigue would have influenced the results.

As expected, the $\mathrm{V}_{T}$ obtained in the simulation of a "normal" patient was higher than that found in the tests using the compliance and resistance settings established by the ASTM criteria, which simulated a patient with decreased compliance and increased resistance, which are proven to lead to a lower $\mathrm{V}_{\mathrm{T}}{ }^{(17)}$

The presence of a PLV in the Brazilian-made MRs possibly impaired their performance. All of the Brazilian-made MRs had a PLV, and in only one of them could the valve be closed. The valves of all of them initially opened at low pressures, the values of which were below the specified value, causing leaks during inflation, which can partially explain the lower $\mathrm{V}_{\mathrm{T}}$ obtained with the RMs that had a PLV. This result can be considered a severe fault, because it can prevent appropriate ventilation in patients with decreased lung compliance or with increased airway resistance, such as those with pulmonary edema and those with asthma attacks, respectively.

According to some authors, the presence of PLV does not bring additional safety to adult patients, ${ }^{(9)}$ given that the risk of barotrauma is not associated only with high peak pressures during inhalation. ${ }^{(19)}$ In fact, the ASTM criteria ${ }^{(7)}$ dispense with the use of a pressure-regulating device for MRs for adults and determine that, if this valve is present, it should be possible to lock it and its closing mechanism should be quite evident to the operator. ${ }^{(6,7)}$ Even in MRs for neonatal/pediatric patients, for which the presence of this valve is recommended in order to limit pressure to values below $40 \pm 5 \mathrm{cmH}_{2} 0,{ }^{(7,20)}$ malfunctioning of the PLV can also impair ventilation. ${ }^{(2)}$

We consider limitations of our study the fact that all tests were performed using only one unit of each MR (however, all MRs were brand-new); that resistance of the patient valve was tested at a flow of $60 \mathrm{~L} / \mathrm{min}$, rather than of $50 \mathrm{~L} / \mathrm{min}$ (value recommended by the ASTM), which can hinder the comparison with other studies; and that, since the present study was carried out in 2006, some MR models underwent changes (Table 1), which might have altered their performances. This should be probably true for the MR manufactured by Unitec, in which the capacity of the bag was significantly increased (Table 1).

Despite the limitations of this study, we believe that important deficiencies of the MRs manufactured in Brazil are reported, especially those regarding the functioning of the PLV (most could not be locked and opened early), deficiencies that, in some clinical conditions, can impair ventilation in critically ill patients. Our results indicate that, in order to deliver an appropriate $V_{T}$, it is necessary that both hands be used to compress the MR bag and that, when allowed by the MR, the PLV be kept closed. We believe that the results obtained in the present study can aid in performing future tests and in improving the Brazilian-made MRs.

\section{References}

1. White GC. Emergency resuscitation equipment. In: White GC, editor. Equipment Theory for Respiratory Care. Clifton Park: Thomson/Delmar Learning; 2005. p. 249-99.

2. Oliveira PM, Almeida-Junior AA, Almeida CC, Ribeiro MA, Ribeiro JD. Fatores que afetam a ventilação com o reanimador manual autoinflável: uma revisão sistemática. Rev Paul Pediatr. 2011;29(4):645-55.

3. Maxwell L, Ellis ER. The effects of three manual hyperinflation techniques on pattern of ventilation in a test lung model. Anaesth Intensive Care. 2002;30(3):283-8. PMid:12075634

4. Stiller K. Physiotherapy in intensive care: towards an evidence-based practice. Chest. 2000;118(6):1801-13. http://dx.doi.org/10.1378/chest.118.6.1801 PMid:11115476

5. Godoy AC, Vieira RJ, Vieira Neto RJ. Oxygen outflow delivered by manually operated self-inflating resuscitation bags in patients breathing spontaneously. J Bras Pneumol. 2008;34(4):212-6. PMid:18425257

6. Dorsch JA, Dorsch SE. Manual Resuscitators. In: Dorsch JA, Dorsch SE, editors. Understanding Anesthesia Equipment. Baltimore: Williams \& Wilkins; 1994. p. 225-38.

7. ASTM International. ASTM Standard F920-93 Standard Specification for Minimum Performance and Safety Requirements for Resuscitators Intended for Use with Humans. West Conshohocken: ASTM International; 1999. 
8. Hess DR. Manual and Gas-Powered Resuscitators. In: Branson RD, Hess DR, Chatburn RL, editors. Respiratory Care Equipment. Philadelphia: Lippincott; 1999. p. 187-204. PMid:10369141

9. Eaton JM. Medical technology. Adult manual resuscitators. Br J Hosp Med. 1984;31(1):67-70. PMid:6697045

10. Mazzolini DG Jr, Marshall NA. Evaluation of 16 adult disposable manual resuscitators. Respir Care. 2004;49(12):1509-14. PMid:15571642

11. International Organization for Standardization. International Standard 1S0 8382: 1988(E). Resuscitators intended for use with humans. New York: American National Standards Institute; 1988.

12. de Godoy AC, Vieira RJ. Comparison of the FiO2 delivered by seven models of the self-inflating bag-mask system. Rev Bras Anestesiol. 2009;59(1):21-7. PMid:19374212

13. Godoy AC, Vieira RJ, De Capitani EM. Alterations in peak inspiratory pressure and tidal volume delivered by manually operated self-inflating resuscitation bags as a function of the oxygen supply rate. J Bras Pneumol. 2008;34(10):817-21. http://dx.doi.org/10.1590/S180637132008001000010 PMid:19009215

14. Barnes TA, McGarry WP 3rd. Evaluation of ten disposable manual resuscitators. Respir Care. 1990;35(10):960-8. PMid:10145334
15. Hess D, Simmons M. An evaluation of the resistance to flow through the patient valves of twelve adult manual resuscitators. Respir Care. 1992;37(5):432-8. PMid:10145632

16. Hess D, Simmons M, Blaukovitch S, Lightner D, Doyle T. An evaluation of the effects of fatigue, impedance, and use of two hands on volumes delivered during bag-valve ventilation. Respir Care. 1993;38:271-5.

17. Hess D, Spahr C. An evaluation of volumes delivered by selected adult disposable resuscitators: the effects of hand size, number of hands used, and use of disposable medical gloves. Respir Care. 1990;35:800-5. PMid:10145317

18. Hess D, Goff G, Johnson K. The effect of hand size, resuscitator brand, and use of two hands on volumes delivered during adult bag-valve ventilation. Respir Care. 1989;34:805-10.

19. Ricard JD. Manual ventilation and risk of barotrauma: primum non nocere. Respir Care. 2005;50(3):338-9. PMid:15779151

20. Zaconeta CAM, Borges MBS, Souza DVB, Marques MG. Avaliação do pico de pressão e da frequência respiratória durante o uso de balão autoinflável por socorristas do Corpo de Bombeiros em um modelo de pulmão neonatal pré-termo. Rev Paul Pediatr. 2010;28(1):5-9. http://dx.doi.org/10.1590/S0103-05822010000100002

\section{About the authors}

\section{Tatiana de Arruda Ortiz}

Physiotherapist. Laboratório de Investigação Médica 09 (L1M09, Laboratory for Medical Research 09), specializing in Pulmonology, University of São Paulo School of Medicine, São Paulo, Brazil.

\section{Germano Forti Junior}

Physiotherapist. Laboratório de Investigação Médica 09 (LIM09, Laboratory for Medical Research 09), specializing in Pulmonology, University of São Paulo School of Medicine, São Paulo, Brazil.

\section{Márcia Souza Volpe}

Adjunct Professor. Department of Applied Physiotherapy, Universidade Federal do Triângulo Mineiro, Uberaba, Brazil.

\section{Marcelo do Amaral Beraldo}

Physiotherapist. Laboratório de Investigação Médica 09 (LIM09, Laboratory for Medical Research 09), specializing in Pulmonology, University of São Paulo School of Medicine, São Paulo, Brazil

\section{Marcelo Britto Passos Amato}

Supervising Physician. Respiratory 1CU, University of São Paulo School of Medicine Hospital das Clínicas, São Paulo, Brazil.

\section{Carlos Roberto Ribeiro Carvalho}

Full Professor of Pulmonology. University of São Paulo School of Medicine, São Paulo, Brazil.

\section{Mauro Roberto Tucci}

Physician. Laboratório de Investigação Médica 09 (LIM09, Laboratory for Medical Research 09), specializing in Pulmonology, University of São Paulo School of Medicine; and A.C. Camargo Cancer Hospital, São Paulo, Brazil. 


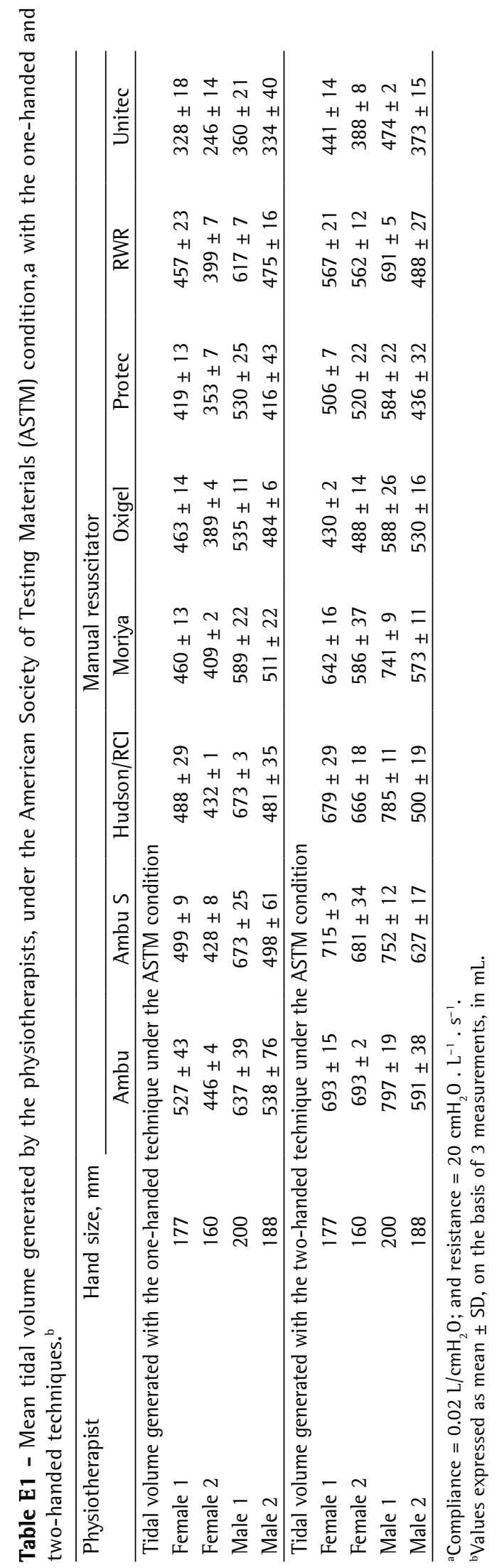

